\title{
Experimental Study of Numerical Relay for Over-current Protection in Solar Panel for Securing the Hydrogen production.
}

\author{
Chawki Ameur menad ${ }^{1, *}$, M. Bouchahdane ${ }^{2}$, and Rabah Gomri ${ }^{1}$ \\ ${ }^{1}$ University Frères Mentouri Constantine 1, Faculty of Sciences and Technology, Department of \\ Génie Climatique, 25000 Constatine, Algeria \\ ${ }^{2}$ Department of Power and control Institute of Electrical and Electronic Engineering, IGEE \\ Boumerdes, Algeria
}

\begin{abstract}
Every electrical system in solar panel can fail during electrical faults. In this incidence, high fault current can occur. Such current must be interrupted by a protective system. The research was supported by experimental tests. In work conditions close to real, the numerical relay REF542plus was tested for both instantaneous and extremely inverse definite minimum time IDMT over-current protection functions with the help of CMC 365 injection and test equipment associated to Test Universe software. Protecting hybrid solar panels generating by different renewable energy sources for hydrogen production from over-current is very important for improving the energy efficiency in one hand, and securing the function in critical condition from damage of the solar cells in second hand. The contribution of this research is controlling the over-current in the solar panel for securing the continuation of the hydrogen production from renewable energy sources in short time. The obtained results allowed the observation of the relay's behavior when subjected to certain faults; where the solar panel keeps producing the hydrogen.
\end{abstract}

\section{INTRODUCTION}

Due to the impact of the safety in solar systems on the energy efficiency in critical situation, an experimental proposal research project was studied for understanding the most important problem which is the over-current in solar systems in Algerian Climate. The solar has been installed for exploiting electricity produced for hydrogen production from $\mathrm{H} 2 \mathrm{SO} 4$ cycle under Algerian climate. Many research projects have been developed about using renewable energy for hydrogen production. Wilson et al [1] have mentioned on their research the objective of generating Hydrogen by solar photovoltaic (PV) array and then collected for data analysis to demonstrate efficiency of the hydrogen production in all the steps of the experiment. Their positive results proofed that the studied case model allows demonstrating at least one hour operation per hydrogen charging at room temperature. Some research papers were focusing just in production of hydrogen by electrolysis powered

${ }^{*}$ Corresponding author: c.ameurmenad@gmail.com 
from wind and solar sources. As a result they got the reasonable price for producing hydrogen from wind and solar energy [2]. Other choice for exploiting solar power for creating new opportunities for hydrogen production, where the final cost estimation for hydrogen and solar electricity generation will show the potential of both technologies for a sustainable energy industry, this research has been developed by Quaschning and Trieb [3]. Amevi Acakpovi, Essel Ben Hagan have studied modeling solar power generation by photovoltaic cell, where the modeling was under Simulink, the obtained results confirmed some novelty comparing to the previous research [4]. Another research have published about design and studying new technique called Support Vector Machine (SVM) based on experimental experience; Kazem et al obtained results proofed that the studied model achieved less MSE in comparing to the previous research about management energy generation [5]. Moreover; Salmi et al developed a new model photovoltaic cell by using Matlab/SIMULINK, the model is based on mathematical equations and described through an equivalent circuit including a photocurrent source. In addition an experimental test bench was built and the obtained results exhibited a good agreement with the simulation ones [6]. Regarding studying novel modeling technique of PV module with a fuzzy logic based MPPT algorithm and boost converter in Simulink environment which was developed by Mahamudul et al [7]. The main result has given a important contribution which is simplification of PV modeling technique and implementation of fuzzy based MPPT system to track maximum power efficiently. Other research about developing methodology for production of hydrogen by electrolysis system was proposed by Ayati et al [8]. However, in Terms of studying the over-current in solar systems; many researchers have been developed by using electrical relay. Barsoum et al [9] have studied overvoltage issue of electricity produced from renewable energy in power grid, the over-current relays due to reserve power to the $33 \mathrm{kV}$. The obtained results is illustrated that the transmission losses are reduced. Finally; Ok et al [10] have published a research about protection relay in wind power systems, where the over-current relay (OCR) based on wind speed. The benefits were verification of false actions by OCR's and the the electrical faults in the power grid can be solved.

Regarding the studying model; the Figure 1 shows the function of solar panel for producing hydrogen from $\mathrm{H}_{2} \mathrm{SO}_{4}$. However; the protection of the hybrid solar panel from over-current has taken the major part.

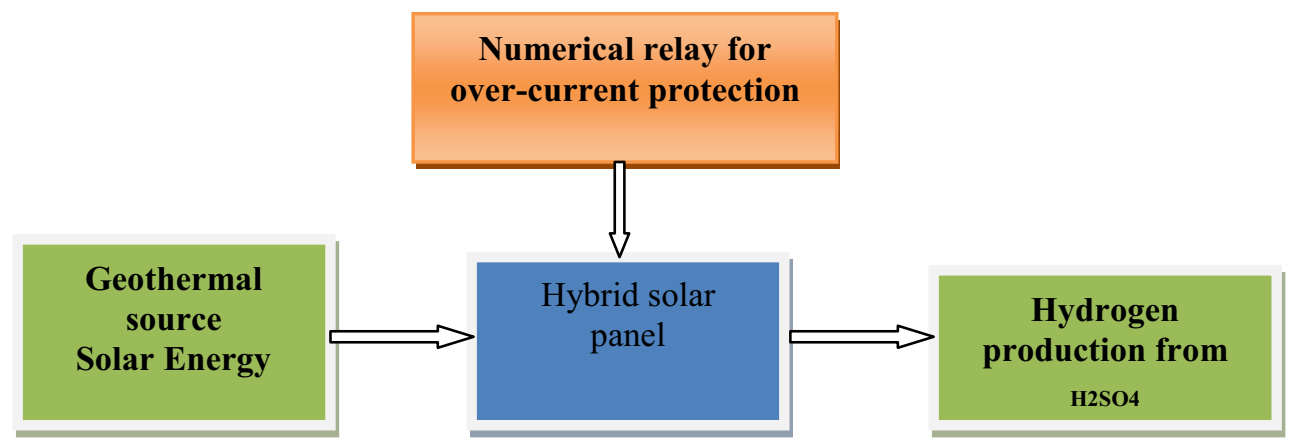

Fig. 1. Description of the studied case

The experience has been developed in Ghardia which is located in the south of Algeria due the presence of the solar panel station. For clarify the electricity capacity available in Algeria from the solar energy, the Figure 2 explains the solar electricity per area in Algeria [11], and the Figure 3 is area where the experience has been developed. 


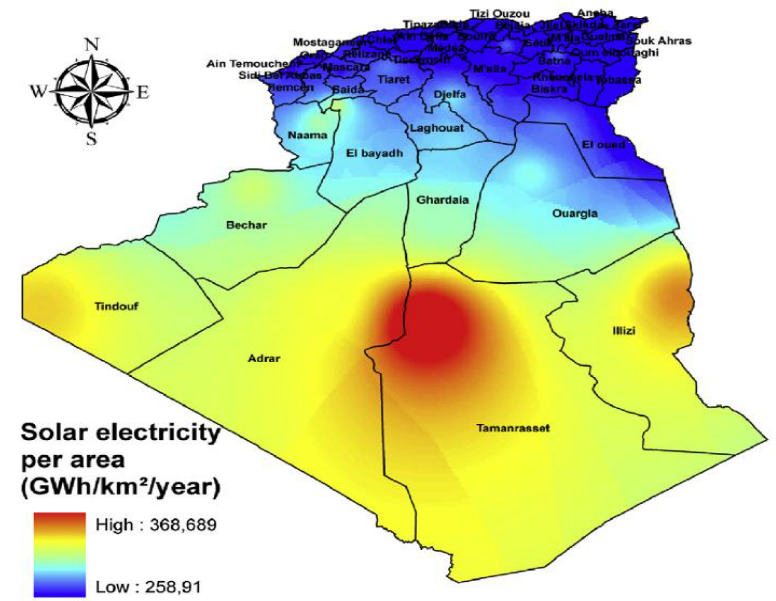

Fig. 2. Solar electricity per area in Algeria

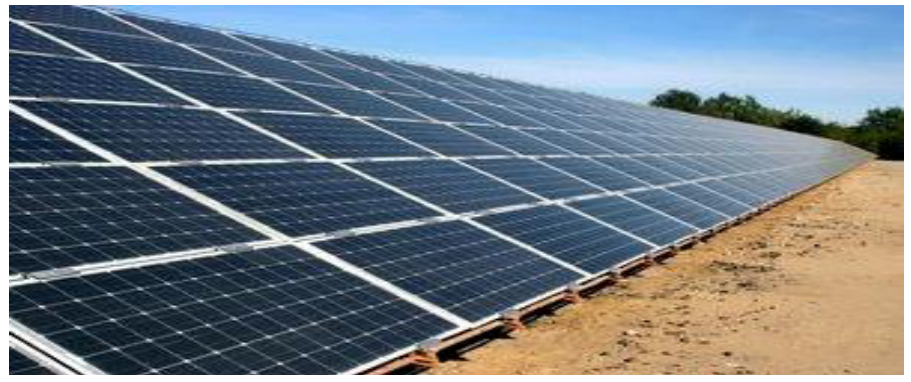

Fig. 3. Solar Power Station in Ghardaia (Algeria).

\section{IMPACT OF OVER-CURRENT ON PV SOLAR EFFICIENCY}

Electrical Power System Protection is required for protection of both the user and the electrical system equipment from faults. It is important to validate the settings of power protection equipment and to confirm its performance when subject to different fault conditions. Consequently, the protective relay testing is very important before any new type of relay is commissioned in practical applications. Therefore; Numerical relays are currently being utilized for ensure various protection functions simultaneously. The overcurrent protection is the most extensively used to safeguard all power systems from the detrimental effects of faults causing high current flows. The fig 4 represents a real impact of over-current on solar system. As a result controlling the power station by installing the numerical relay REF542plus in Ghardia solar power station is very important to avoid technical problems in one side, and secure hydrogen production in the other side. 


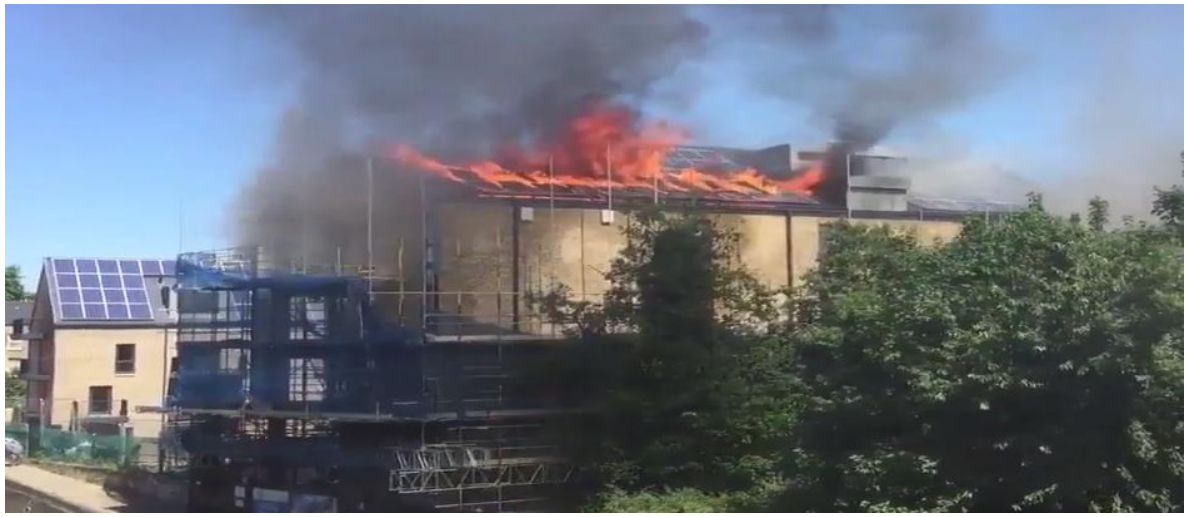

Fig. 4. Risk of Over-Current in PV Solar Panels [12].

\section{PRACTICAL STUDY (OVER-CURRENT) IN SOLAR PANEL SYSTEM}

Like any other device, the numerical over-current relay should be tested before its installation in the area to be protected. In this part, we will discuss one of the newest methods of testing which was realized in the laboratory.

The practical part consists testing a numerical Relay for protecting the solar panel from damage, and securing the continuation of the hydrogen production. So the passage from the first part which production of electricity from renewable energies to second part which hydrogen production has to pass this practical test.

In this part, we interfaced the relay under test to a PC through an optical connector placed in the front of the HMI. This interface permits to download the relay's configuration file from/to the PC. The base unit and the HMI of the relay are supplied with $100 \mathrm{~V}$ dc and $48 \mathrm{~V}$ dc respectively and are connected to each other using the physical interface RS485 standard connector. In the other side, we directly feed the CMC356 with 220V AC supply and linked to the relay using cables coming out of its three phase voltage and current outputs and going to the analog input module of the relay's base unit. This connection permits the CT and VT located inside the CMC356 to sense and to measure the injected voltages and currents before sending them to the relay. The communication between CMC356 and the PC where Test Universe is installed was done using an Ethernet cable. After finishing the connections above, the CMC356 and the relay were turned on, the relay was reset and so, ready to be tested. Figure 5 shows the REF452 plus and CMC356 connected together in the laboratory for tests.

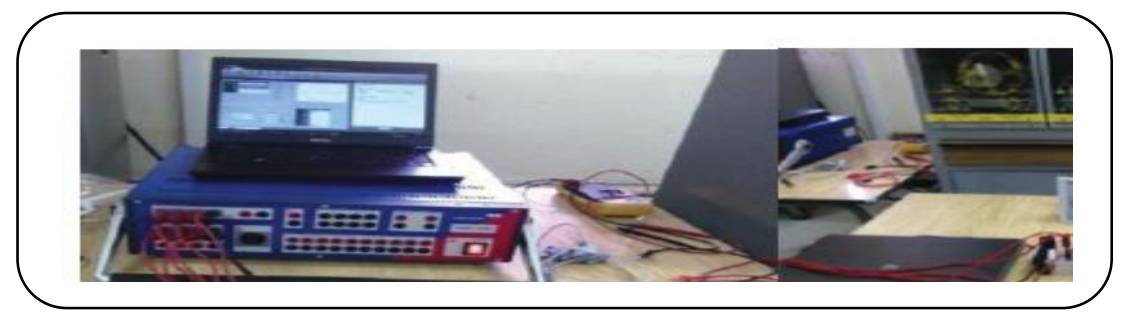

Fig 5. Studied Test of Over-Current in PV Solar panel. 


\section{PROSPECTS OF HYDROGEN PRODUCTION FROM HTES SYSTEM IN STABLE CASE AND INSTABLE CASE}

\subsection{Proposed Panel}

Production of hydrogen from $\mathrm{H} 2 \mathrm{SO} 4$ at $622^{\circ} \mathrm{C}$ in the studied case is possible by using the HTES technology where the temperature varied between $600^{\circ} \mathrm{C}$ and $1000^{\circ} \mathrm{C}$. However there is another possibility to increase the temperature until 1000 from the same hybrid solar panel, and start producing hydrogen from different cycles. The Figure 6 shows the selected solar panel.

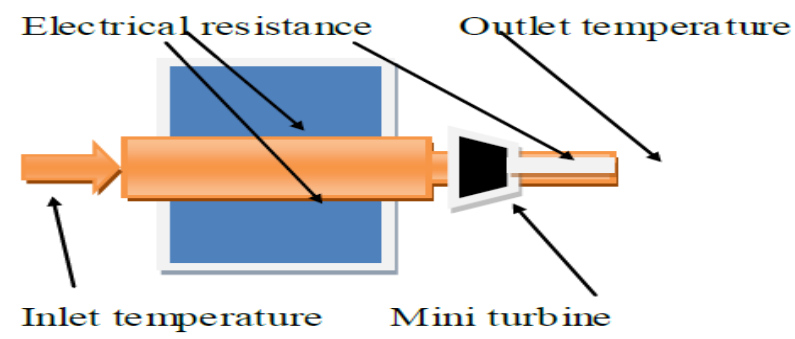

Fig. 6. Proposed PV Solar Panel

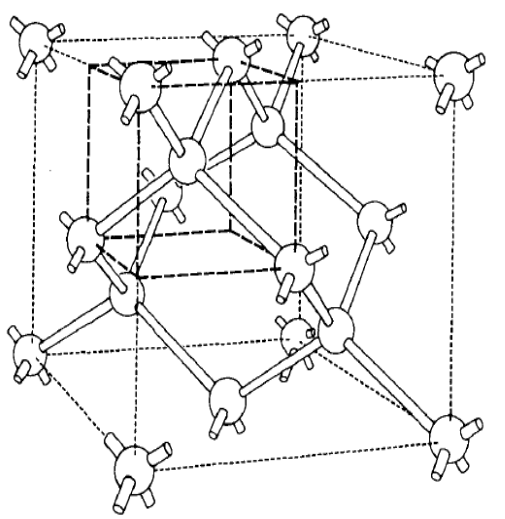

Fig. 7. Representation of the Silicon Crystal Lattice Arrangement [13]

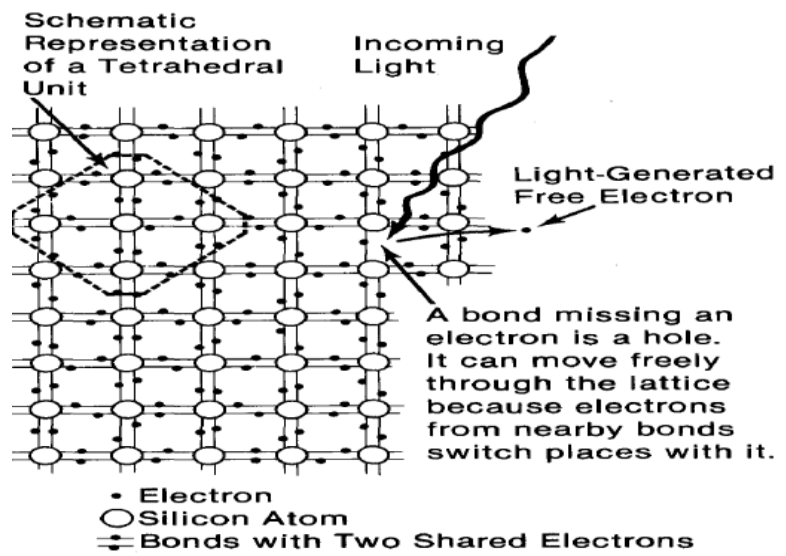

Fig. 8. Light Sufficient Energy Can Generate Electron Hole Pairs in Silicon [13] 
In terms of hydrogen production from the selected solar panel; $\mathrm{H} 2 \mathrm{SO} 4$ cycle has been selected for understanding the impact of the over-current on selected systems

$\mathrm{H} 2 \mathrm{SO} 4$.

$$
\begin{array}{ll}
\mathrm{SO}_{2}+\mathrm{I}_{2}+2 \mathrm{H}_{2} \mathrm{O} \rightarrow \mathrm{H}_{2} \mathrm{SO}_{4}+2 \mathrm{HI} & \left(100^{\circ} \mathrm{C}-130^{\circ} \mathrm{C}\right) \\
\mathrm{H}_{2} \mathrm{SO}_{4} \rightarrow \mathrm{SO}_{2}+\mathrm{H}_{2} \mathrm{O}+1 / 2 \mathrm{O}_{2} & \left(800^{\circ} \mathrm{C}-1000^{\circ} \mathrm{C}\right) \\
2 \mathrm{HI} \rightarrow \mathrm{H}_{2}+\mathrm{I}_{2} & \left(300^{\circ} \mathrm{C}-400^{\circ} \mathrm{C}\right)
\end{array}
$$

Productivity of Hdrogen from $\mathrm{H}_{2} \mathrm{SO}_{4}$ is:

$295.5 \mathrm{MJ} / \mathrm{KgH}_{2}$

\section{RESULTS AND DISCUSSIONS}

Controlling the over-current by installing Numerical Relay REF542plus is one of the most important factors for securing the hydrogen production and increasing the energy efficiency. The Table1 shows that amount of $\mathrm{H}_{2}$ produced dropped by $89.537 \%$ in case of over-current uncontrolled (Absence of Numerical Relay REF542plus).

Table 1. Impact of Over-current on Hydrogen production from Hybrid Solar Panel from $\mathrm{H}_{2} \mathrm{SO}_{4}$.

\begin{tabular}{|c|c|}
\hline Conditions of Hydrogen production & Amount of hydrogen $\left(\mathrm{Kg} \mathrm{H}_{2}\right)$ \\
\hline $\begin{array}{c}\text { 1/ PV solar panel under control (presence of } \\
\text { Numerical Relay: REF542plus) }\end{array}$ & $0,517 \mathrm{Kg} \mathrm{H}_{2} / \mathrm{day}$ \\
\hline $\begin{array}{c}\text { 2/ PV Solar panel Instable due to over-current } \\
\text { (absence of Numerical Relay: REF542plus) }\end{array}$ & $0,05409 \mathrm{Kg} \mathrm{H}_{2} /$ day \\
\hline
\end{tabular}

\section{CONCLUSION}

The aim of this project was to offer a good reference about the over-current protection. The Numerical Relay is the most appropriate for this type of protection, because it can accommodate different types of relay functions and provide an easy modification to tripping characteristics and change in conventional setting. Wrong settings in over-current relay parameters can lead to serious problems; therefore, testing it before any use is necessary and requires a full study to guarantee its efficient performance for all time. The test experiment for over-current function, performed on the relay confirms the correctness of its operation in accordance with manufacturer's design and suitability for intended application. The results were satisfactory and as expected.

The amount of hydrogen production in case of over-current none controlled is lower by $89.537 \%$ than the normal case in the proposed hybrid solar panel.

\section{References}

1. J. F. Wilson, S. S. Srinivasan, B. M. Moore, L. Henderson, S. Ely, P.C. Sharma, Hydrogen Production Using Solar Energy, Journal of undergraduate research in physics 17/03/2013.

2. M. Douaka, N. Settoub, Estimation of hydrogen production using wind energy in Algeria, Energy Procedia 74, 981-990, (2015) 
3. V. Quaschning and F. Trieb, Solar Thermal Power Plants For Hydrogen Production, Hypothesis, IV Symposium Stralsund, Germany 9-14 September 2001, pp.198-202.

4. A. Acakpovi, E.B. Hagan, Novel Photovoltaic Module Modeling using Matlab/Simulink, International Journal of Computer Applications, 2013 by IJCA Journal

5. Al-Waeli, A. H. A., Sopian, K., Kazem, H. A., Yousif, J. H., Chaichan, M. T., Ibrahim, A., Ruslan, M. H., Comparison of prediction methods of PV/T nanofluid and nano PCM system using a measured dataset and artificial neural network. Solar Energy, 162, 378- 396, (2018).

6. T. Salmi, M. Bouzguenda, A. Gastli, A. Masmoudi, MATLAB/Simulink Based Modelling of Solar Photovoltaic Cell, International Journal of Renewable Energy Research, Vol.2, No.2, (2012).

7. H. Mahamudul, M. Saad, M. I. Henk, Photovoltaic System Modeling with Fuzzy Logic Based Maximum Power Point Tracking Algorithm, International Journal of Photoenergy Vol. , (2013).

8. F. Ayati, A. M'Raoui, M. Belhamel, A. Rebai, Modélisation d'un Système de Production d'Hydrogène Solaire par Electrolyse, Rev. Energ. Ren. Vol. 7, 135$150,(2004)$

9. N. Barsoum, C. Z. Lee, Simulation of Power Flow and Protection of a Limited Bus Grid System with Injected Solar Power, Energy and Power Engineering, Vol. 5, 59-69, (2013).

10. Y. Ok, J. Lee, J. Choi, Analysis and Solution for Operations of Overcurrent Relay in Wind Power System Energies, Vol 9, 458, (2016).

11. S. Rahmouni, B. Negrou, N. Settou J. Dominguez, A. Gouareh, Prospects of hydrogen production potential from renewable resources in Algeria, International Journal of Hydrogen Energy Vol. 42, 1383-1395, (2017) .

12. https://www.solarpowerportal.co.uk/news/solar_pv_fires_predominantly_caused_ by_inst aller_error_government_report_co.

13. Technical information office, U.S Department of Energy, Basic Photovoltaic Principles and Methods, February 1982, SERI/SP-290-1448. 